\title{
REVITALISASI SYARIAT ISLAM SEBAGAI PEDOMAN HIDUP MANUSIA
}

\author{
Arijulmanan \\ (STAI Al-Hidayah, Dosen Prodi HI) \\ Received: 04-10-2018, Accepted: 15-10-2018, Published: 26-10-2018
}

\begin{abstract}
Islamic Sharia is so beautiful, giving life guidance not only in the hereafter but also in this world. Islam does not only command maghdoh worship (rituals) but also worship ghoiru maghdoh (general). Islamic Sharia aims to save people in the world and in the hereafter. Islam is a comprehensive and universal religion which includes worship and muamalah. The decline of Islamic sharia, known as maqashid as-sharia (the purpose and objective of sharia) has 5 (five) objectives, the five maqashid (goals) are: Hifdz Ad-Din (guarding religion), Hifdz An-Nafs (guarding the soul), Hifdz Al-'Aql (guarding reason), Hifdz An-Nasab (guarding offspring) and Hifdz Al-Mal (guarding property). Pillars of Islamic buildings include Tawheed, Morals and Sharia. Through the application of Islamic sharia will be realized justice, security, prosperity and brotherhood for humanity
\end{abstract}

\begin{abstract}
Abstrak
Syariah Islam begitu indah, memberikan pedoman hidup bukan hanya di akhirat tetapi juga di dunia ini. Islam bukan hanya memerintahkan ibadah maghdoh (ritual) tapi juga ibadah ghoiru maghdoh (umum). Syariah Islam bertujuan menyelamatkan manusia di dunia dan di akhirat. Islam merupakan agama yang komprehensif dan universal yang meliputi ibadah dan muamalah. Diturunkannya syariah Islam ini yang dikenal dengan maqashid as-syariah (maksud dan tujuan syariah) mempunyai 5 (lima) tujuan, kelima maqashid (tujuan) tersebut adalah : Hifdz Ad-Din (menjaga agama), Hifdz An-Nafs (menjaga jiwa), Hifdz Al- 'Aql (menjaga akal), Hifdz An-Nasab (menjaga keturunan) dan Hifdz Al-Mal (menjaga harta).Pilar bangunan Islam meliputi Tauhid, Akhlak dan Syariah. Melalui penerapan syariah Islam akan terwujud keadilan, keamanan, kemakmuran dan persaudaraan bagi ummat manusia.
\end{abstract}

Kata Kunci: Islam, Syariah, Maqashid 


\section{A. PENDAHULUAN}

Konsep bangunan Islam, terlihat dua hal yang saling terkait yakni keimanan (Faith) dan Islam, ia adalah dua istilah yang memiliki makna yang sinonim ketika terpisah dan memiliki makna khusus ketika menjadi satu rangkaian. Iman bermakna keyakinan dalam hati yang terucap oleh lisan dan diamalkan oleh anggota badan. Iman bersifat abstrak dan hanya dirinya dan Allah saja yang mengetahuinya, manusia lain hanya mampu melihat indikasiindikasinya saja. Secara sederhana dapat disebutkan bahwa iman adalah amalan hati sedangkan Islam adalah amalan anggota badan.

Revitalisasi adalah suatu proses atau cara dan perbuatan untuk menghidupkan kembali suatu hal yang sebelumnya terberdaya sehingga revitalisasi berarti menjadikan sesuatu atau perbuatan untuk menjadi vital, sedangkan kata vital mempunyai arti sangat penting atau sangat diperlukan sekali untuk kehidupan dan sebagainya. ${ }^{1}$

1 Tim Pusat Studi Pancasila UGM. (2014). Prosiding Kongres Pancasila. Yogyakarta: Pusat Studi Pancasila, hlm. 220.
Pengertian dari revitalisasi bisa berarti proses, cara dan atau perbuatan untuk menghidupkan atau menggiatkan kembali berbagai program kegiatan apapun. Sehingga secara umum pengertian dari revitalisasi merupakan usaha-usaha untuk menjadikan sesuatu itu menjadi penting dan perlu sekali. ${ }^{2}$

Syariah berarti ketentuan agama yang telah ditetapkan oleh Allah S.W.T. untuk hamba-Nya, yang berupa berbagai hukum dan ketentuan tersebut disebut sebagai syariah karena bentuknya yang konsisten sebagaimana yang dijelaskan dalam surah Al-Ma'idah: 30 bahwa Allah meridhai Islam sebagai agama penyempurna umat manusia.

Syariat Islam akan selalu memiliki maslahat bagi manusia, baik didunia maupun di akhirat. Syariah juga, dimaksudkan untuk menghilngkan mafsadah atau minimal menguranginya. Artinya, syariah islam membawa misi bagi lahirnya maqhasid syari'ah. Contohnya dalam syari'ah Islam menetapkan haramnya riba, serta beberapa ketentuan lainnya yang

2 Tim Pusat Studi Pancasila UGM. (2014). Prosiding Kongres Pancasila. Yogyakarta: Pusat Studi Pancasila, hlm. 220. 
ditetapkan terkait hal tersebut. Penerapan aturan tersebut, baik dalam wilayah indivdu maupun masyarakat, akan membawa pengaruh baik bagi umat manusia.

Pertimbangan maslahat sering menjadi pinjakan dalam setiap penentuan hukum. Namun tentunya akal tidak bisa dibiarkan bebas untuk menentukan maslahat, maka seebaliknya syariat lah yang harus menentukannya. Karena itu, kemaslahatan itu pada dasarnya adalah sesuatu yang tauqifi, bukan akal. Dan syariah Islam adalah aturan dan ketentuan yang datangnya dari dzat yang paling mengetahui hakekat manusia.

Jadi secara keseluruhan, syariah Islam mengandung kemaslahatan. Sehingga, umat Islam membutuhkan penerapan syariat Islam karena seluruh kemaslahatan yang besar yang terdapat didalamnya menuntun kita pada sebuah kebaikan dan kebenaran.

\section{B. PEMBAHASAN}

1. Apa Itu Islam?

Secara etimologi kata Islam berasal dari bahasa Arab yaitu "S L M"
(Sin, Lam, Mim) artinya antara lain: damai, suci, patuh dan taat (tidak pernah membantah). ${ }^{3}$ Sedangkan dalam pengertian syar'i, kata Islam berarti kepatuhan kepada kehendak dan kemauan Allah, serta taat kepada hukum-Nya. Sehingga hubungan antara pengertian menurut pengertian kata dasar dengan pengertian seacara syar'i tadi sangat erat sekali kaitannya sehingga diperoleh pengertian yakni: "Hanya dengan kepatuhan kepada kehendak Allah dan tunduk kepada hukum-hukum-Nya seseorang dapat mencapai kedamaian sesungguhnya dan memperoleh kesucian yang abadi. ${ }^{4}$

Penjelasan yang lain tentang pengertian Islam dikemukakan oleh Abul A'la Maududi, beliau memberikan pengertian secara ringkas terhadap arti kata Islam yakni “Taat kepada Allah dan tunduk kepada perintah-Nya tanpa membantah. ${ }^{5} \quad$ Dalam konteks tafsir Quraish Shihab memberikan penjelasan bahwa nama Islam mengandung arti

\footnotetext{
${ }^{3}$ Ibnu Mandzur. Lisan Al-'Arab Juz VI. hlm. 344 .

4 Hammudah Abdalati. (1407/1986). Islam Suatu Kepastian. Jakarta: I.I.F.S.O, hlm. 13.

5 Abul A'la Maududi. (1407 H/ 1986). Prinsip-Prinsip Islam. Jakarta: International Islamic Federation of Student Organizations, hlm. 2 .
} 
dan makna "Ajaran yang mendambakan perdamaian". 6

Secara lebih komprehensif pengertian atau definisi tentang Islam sekurang-kurangnya mengandung lima pengertian sebagai berikut: ${ }^{7}$

Pertama, bersumber dari sebuah hadist sebagai berikut:

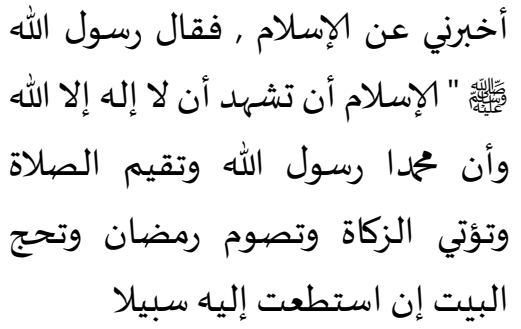

Ceritakan kepadaku (wahai Muhammad) tentang Islam!

Rasulullah menjawab: Kau mengakui tiada Tuhan selain Allah, Muhammad adalah hamba-Nya dan Rasul Allah, mendirikan sholat, mengeluarkan zakat, berpuasa pada bulan Ramadhan dan berhaji ke baitullah jika mampu. H.R. Bukhari dan Muslim.

${ }^{6}$ M Quraish Shihab. (1499 H/ 1999). Wawasan Al Quran. Jakarta: Penerbit Mizan, hlm. 378.

7 Abdul Karim Zaidan. (1979). Dasardasar Ilmu Dakwah (1). Jakarta: Media Dakwah, hlm. 3-13.
Kedua, Islam ialah berserah diri kepada Allah dengan tauhid dan tunduk kepada-Nya dengan penuh kepatuhan pada segala perintah-Nya serta menyelamatkan diri dari perbuatan syirik dan orang-orang yang berbuat syirik. $^{8}$ Selain itu, Islam berarti tunduk, menyerah dan mentaati Allah dan ketundukan itu hendaknya lahir dari kesadaran, bukan karena terpaksa. Ketundukan karena terpaksa adalah merupakan sesuatu yang alami bagi setiap makhluk, dan ketundukan yang seperti ini tidak mengakibatkan timbulnya pahala atau siksa, Allah Subhanahu wa Ta'ala berfirman:

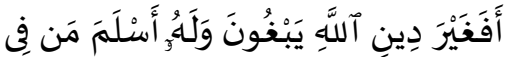

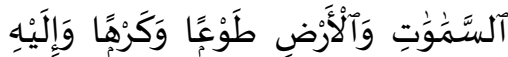

$$
\begin{aligned}
& \text { يُرْجَعُونَ } \\
& \text { Maka apakah mereka } \\
& \text { mencari agama yang lain dari }
\end{aligned}
$$

${ }^{8}$ Syaikh Muhammad At-Tamimi. Tiga Landasan Utama (Islamic Propagation Office in Rabwah). Riyadh: hlm. 49. 
Seluruh makhluk di alam semesta ini tunduk di bawah ketentuan Allah, baik dari segi kejadian, kekal dan fananya, dan dalam bidang ini manusia tidak berbeda dengan makhluk-makhluk lainnya. Adapun ketundukan dengan penuh kesadaran adalah merupakakn hakekat Islam, dan dalam ketundukan yang seperti ini barulah timbul adanya pahala dan siksa. sebagai bukti penuh ketundukan kepada Allah adalah ridha menerima agama-Nya, yang diiringi pula dengan penuh kesadaran. Karena itu, Islam dalam pengertian ini adalah merupakan agama Allah yang diridhaiNya, agama yang diwahyukan kepada Rasul-Nya dan disampaikan kepada seluruh ummat manusia Allah Subhanahu wa Ta'ala berfirman dalam QS. Ali Imran: 19

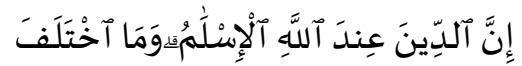

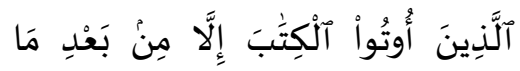

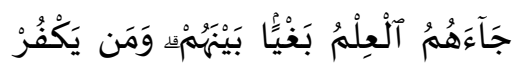

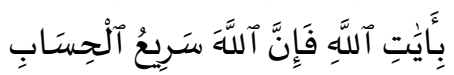

Sesungguhnya agama (yang diridhai) disisi Allah hanyalah Islam. tiada berselisih orangorang yang telah diberi $\mathrm{Al}$ Kitab kecuali sesudah datang pengetahuan kepada mereka, karena kedengkian (yang ada) di antara mereka. Barangsiapa yang kafir terhadap ayat-ayat Allah Maka Sesungguhnya Allah sangat cepat hisab-Nya".

Kemudian dalam Al-Quran Surat Luqman Ayat 22:

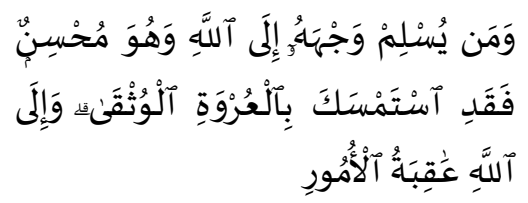

Dan Barangsiapa yang menyerahkan dirinya kepada Allah, sedang Dia orang yang berbuat kebaikan, Maka Sesungguhnya ia telah berpegang kepada buhul tali yang kokoh. dan hanya kepada Allah-lah kesudahan segala urusan".

Juga dijelaskan dalam Al Quran Surat Al-Baqarah Ayat 132-133:

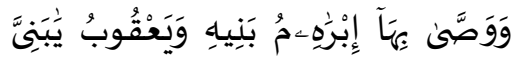

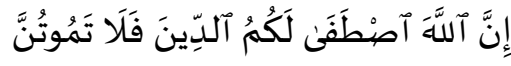

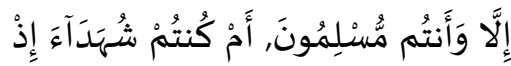

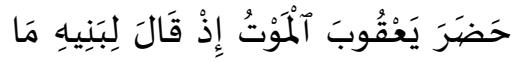

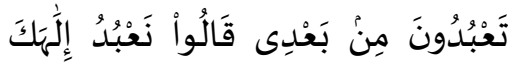

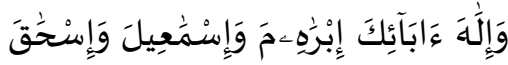

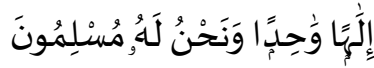

$$
\begin{aligned}
& \text { Dan Ibrahim telah } \\
& \text { mewasiatkan ucapan itu } \\
& \text { kepada anak-anaknya, } \\
& \text { demikian pula Yakub. }
\end{aligned}
$$


(Ibrahim berkata): "Hai anakanakku! Sesungguhnya Allah telah memilih agama ini bagimu, maka janganlah kamu mati kecuali dalam memeluk agama Islam". Adakah kamu hadir ketika Yakub kedatangan (tanda-tanda) maut, ketika ia berkata kepada anak-anaknya: "Apa yang kamu sembah sepeninggalku?" Mereka menjawab: "Kami akan menyembah Tuhanmu dan Tuhan nenek moyangmu, Ibrahim, Ismail dan Ishak, (yaitu) Tuhan Yang Maha Esa dan kami hanya tunduk patuh kepada-Nya."

Ketiga, Islam adalah way of life, peraturan yang bersifat integral yang mengatur hidup dan kehidupan ummat manusia dan menjadi dasar akhlak yang mulia yang dibawa oleh Nabi Muhammad S.A.W. untuk disampaikan kepada ummat manusia. Bagi yang mentaatinya diberikan pahala dan bagi orang yang mengingkarinya dikenakan siksa sebagaimana Allah berfirman:

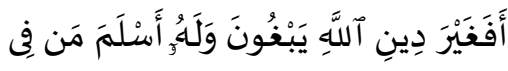

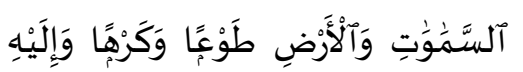

$$
\begin{aligned}
& \text { يُرْجَعُونَ } \\
& \text { Maka apakah mereka } \\
& \text { mencari agama yang lain dari } \\
& \text { agama Allah, padahal } \\
& \text { kepadaNya-lah berserah diri }
\end{aligned}
$$

Agama yang dimaksudkan di sini adalah agama Islam yang menurut pengertian yang kami terangkan sebelumnya, ialah agama Islam yang dibawa oleh Nabi Muhammad S.A.W.

Keempat, Agama Islam merupakan kumpulan peraturan yang diturunkan Allah kepada Rasul-Nya, baik peraturan yang berbentuk kepercayaan, akhlak, ibadat, muamalat dan sejarah yang terkandung di dalam Al-Quran dan sunnah Rasul-Nya, dan diperintahkan untuk menyampaikan kepada ummat manusia. Allah berfirman: 


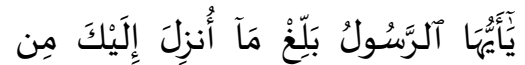

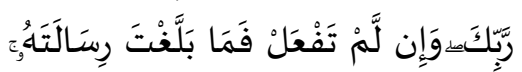

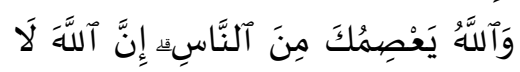

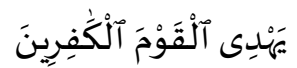

Hai rasul, sampaikanlah apa yang diturunkan kepadamu dari Tuhanmu. dan jika tidak kamu kerjakan (apa yang diperintahkan itu, berarti) kamu tidak menyampaikan amanat-Nya. Allah memelihara kamu dari (gangguan) manusia.

Sesungguhnya Allah tidak memberi petunjuk kepada orang-orang yang kafir." (QS. Al-Maidah: 67)

Kelima, Islam adalah jawaban terhadap tiga persoalan yang selalu dihadapi oleh ummat manusia. Yaitu masalah hubungan manusia dengan tuhan, manusia dengan manusia lainnya dan manusia dengan alam sekitarnya.

Keenam, Islam adalah pedoman hidup yang sebenarnya, petunjuk dalam semua aspek hidup dan kehidupan ummat manusia, obat mujarab untuk mengatasi dan memperbaiki masyarakat dan jalan yang lurus bagi orang-orang yang bersedia untuk mengikutinya. Allah S.W.T. berfirman:

$$
\begin{aligned}
& \text { وَأَوْحَيْنَا إلَنَّ مُوسَنَّ أَنْ أَسْرِ بِعِبَادِيَ }
\end{aligned}
$$

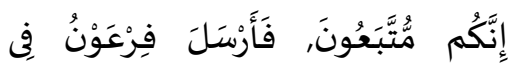

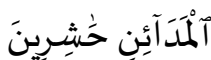

$$
\begin{aligned}
& \text { Dan Kami wahyukan } \\
& \text { (perintahkan) kepada Musa: } \\
& \text { "Pergilah di malam hari }
\end{aligned}
$$

Demikianlah pengertian dari Islam, ia merupakan pedoman hidup yang dianugerahkan oleh Allah Ta'ala kepada umat manusia agar mereka senantiasa berada di jalan-Nya sehingga mereka akan mendapatkan kebahagiaan di dunia dan di akhirat. Dalam ruang lingkup ekonomi maka Islam adalah satu-satunya system ekonomi yang akan membawa kemashalahatn bagi seluruh umat manusia, membawa keadilan, pemerataan harta dan menghilangkan kesenjangan antara si kaya dengan si miskin. 
2. Islam Agama Komprehensif dan Universal

Syariah Islamiyah adalah undangundang yang komprehensif dan universal. Komprehensif berarti meliputi semua aspek dan bidang kehidupan yang secara garis besar dapat diklasifikasi menjadi tiga sub-sistem yaitu: Tauhid, Syari'ah dan Akhlaq. Tauhid adalah hukum-hukum yang bersangkut-paut dengan keimanan dan ketauhidan yang merupakan dasar keislaman seorang muslim. Syari'ah adalah hukum-hukum yang mengatur hubungan manusia dengan Khaliq maupun dengan makhluk. Sedangkan Akhlaq menitikberatkan pada pendidikan rohani dan pembersihan hati dari sifatsifat tercela dan menghiasi dengan sifatsifat yang terpuji.

Syariat ini merupakan ciptaan Allah S.W.T., maka ia tidak terbatas oleh ruang dan waktu, maka ia adalah sistem yang universal. Ia sesuai untuk sepanjang zaman dan semua tempat, tidak lapuk ditelan zaman dan tidak kering dimakan hari. Prinsip Syari'ah Islamiyah tidak dapat berubah, walaupun hukum-hukum cabangnya mungkin dapat berubah. Keadaan geografis, jarak dan perbedaan alam tidak menjadi sebuah halangan bagi kecocokan dan keunggulan sistem ini, karena hukum Islam bukan diciptakan oleh manusia melalui fikiran, pengetahuan dan pengalamannya. Ia merupakan ciptaan Sang Khaliq yaitu Allah S.W.T., Tuhan yang Maha Mengetahui dan Maha Mencipta alam semesta.

\subsection{Islam Agama Komprehensif}

Syari'ah Islamiyah dan seluruh hukumnya tidak boleh dipisah-pisahkan atau dipecah-pecah, karena ia bersifat satu kesatuan (kully). Mengambil sebahagian-sebahagian dan meninggalkan sebahagian yang lain tidak akan dapat mencapai obyektifitas Syari'ah; tujuan dan falsafahnya tidak akan dapat ditegakkan. Bahkan perbuatan seperti ini bertentangan dengan tuntutan Syari'ah dan nash-nash hukum. Beriman dengan sebagian ayat Al-Qur'an dan mengingkari sebagian yang lain membawa seorang hamba kepada suatu kehinaan. Sikap seperti ini tidak akan membawa kepada kebaikan dan kemuliaan kepada ummat Islam. Allah berfirman dalam surah AlBaqarah: $85^{9}$

${ }^{9}$ H. Salim Bahreisy dan H.Said Bahreisy. Terjemah Singkat Tafsir Ibnu Katsir. Jilid I, CV Diponegoro, Bandung, hlm. 154. 


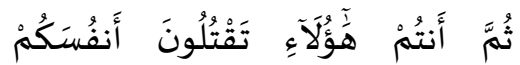

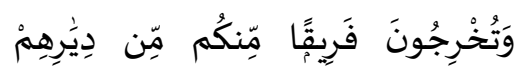

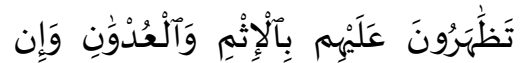

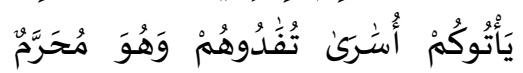

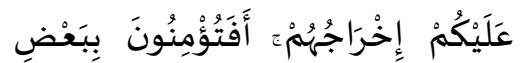

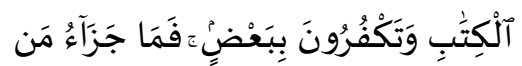

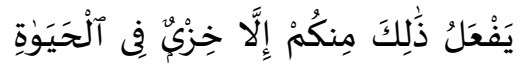

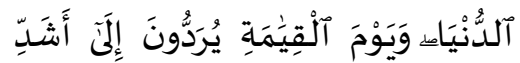

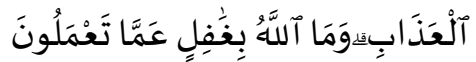

Apakah kamu beriman kepada sebagian Al-Kitab dan ingkar terhadap sebahagian yang lain? Tiadalah balasan kebaikan bagi orang yang berbuat demikian daripadamu, melainkan kenistaan dalam kehidupan dunia, dan pada hari kiamat mereka dikembalikan kepada siksa yang sangat berat. Allah tidak lengah dari apa yang kamu perbuat.

Begitu juga Allah berfirman dalam surah An-Nisa: 150-151: ${ }^{10}$

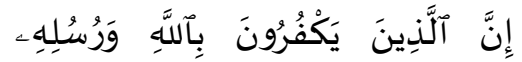

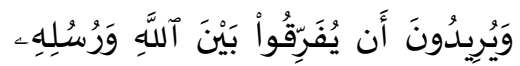

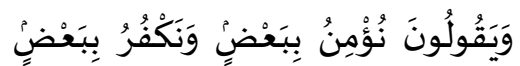

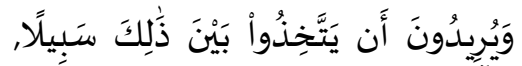

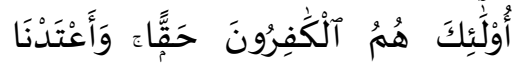

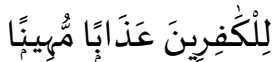

Sesungguhnya orang-orang yang kafir kepada Allah dan

10 H. Salim Bahreisy dan H. Said Bahreisy. Terjemah Singkat Tafsir Ibnu Katsir. hlm. 592.

$$
\begin{aligned}
& \text { rasul-rasul-Nya, dan } \\
& \text { bermaksud membeda- } \\
& \text { bedakan antara Allah dan } \\
& \text { rasul-rasul-Nya dengan } \\
& \text { mengatakan: "Kami beriman } \\
& \text { kepada yang sebahagian dan } \\
& \text { kami kafir terhadap }
\end{aligned}
$$

Syariah Islam adalah sebuah aturan yang komprehensif, ia mengatur seluruh sendi kehidupan manusia. AlQur'an sendiri sebagai pedoman dalam Islam telah menjelaskan segala sesuatu dengan sempurna. Allah ta'ala berfirman:

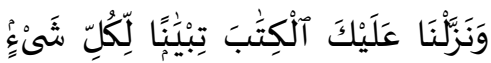

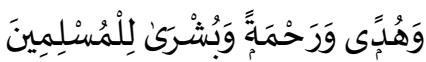

Dan Kami turunkan kepadamu Al-Kitab (Al-Qur'an) untuk menjelaskan segala sesuatu dan petunjuk serta rahmat dan kabar gembira bagi orang- 
orang yang berserah diri. (QS.

An-Nahl: 89)

Ayat yang mulia ini menjelaskan kepada kita bahwa segala sesuatu yang berkaitan dengan kehidupan manusia sudah dijelaskan di dalam Al-Qur'an, baik penjelasan itu secara global misalnya dalam urusan-urusan dunia ataupun bersifat rinci seperti dalam masalah waris.

Dalam ruang lingkup keagamaan maka Islam telah menetapkan bagianbagian dari agama, dalam arti agama ini sudah sangat sempurna dan sangat rinci dalam menjelaskan bagaimana tata cara beribdah kepada-Nya, Allah ta'ala berfirman:

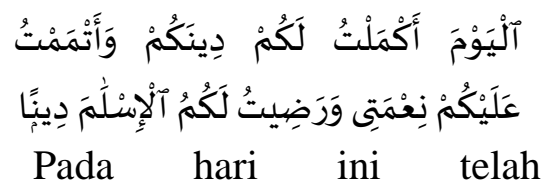

Kusempurnakan untuk kamu agamamu, dan telah $\mathrm{Ku}-$ cukupkan kepadamu nikmat$\mathrm{Ku}$, dan telah $\mathrm{Ku}$-ridai Islam itu jadi agama bagimu. QS. Al-Maidah: 3.

Imam Ibnu Katsir menafsirkan ayat ini dengan berkata: "Ayat ini adalah bukti keagungan anugerah dari Allah ta'ala kepada umat Islam yaitu dengan disempurnakannya agama ini, sehingga ia tidak membutuhkan agama yang lainnya, tidak juga membutuhkan Nabi yang lain selain Muhammad Shalallahu Alaihi wasalam. Allah telah menjadikannya penutup para Nabi, mengutusnya untuk manusia dan jin dan tidaklah sesuatu yang halal kecuali telah beliau halalkan dan sesuatu yang haram telah diharamkan dan tidak ada agama kecuali yang telah disyariatkannya yaitu Islam“. Ucapan beliau ini menunjukan bahwa di dalam Al-Qur'an disebutkan secara rinci seluruh sendi-sendi syariah yang mengatur kehidupan manusia, dalam hal ini adalah permasalahan agama.

Adapun dalam masalah keduniaan maka Rasulullah telah menetapkan batasan-batasannya dengan aturan yang jelas, beliau bersabda:

$$
\text { أَنْتُمْ أَعْلَمُ بِأُمُوْرِ دُنْيَاكُمْ }
$$

Kalian lebih mengetahui tentang urusan dunia kalian”.

HR. Bukhory

Ini adalah pedoman yang sangat egaliter dalam memberikan kebebasan kepada manusia untuk berekspresi dan berinovasi terutama berkaitan dengan masalah-masalah keduniaan, misalnya mengembangkan praktek-praktek bisnis 
yang islami, menciptakan berbagai produk yang innovative, bereksperimen untuk menghasilkan benda-benda yang dibutuhkan manusia dan segala urusan keduniaan lainnya.

\subsection{Islam Agama Universal}

Selanjutnya Islam juga adalah agama yang universal, dalam hal ini ia tidak tersekat oleh waktu dan tempat. Walaupun Islam diturunkan di Arab namun bukan berarti Islam adalah Arab, keduanya adalah dua hal yang bisa berbeda. Al-Qur'an sendiri tidaklah diturunkan hanya untuk orang Arab saja, di dalam Al-Qur'an Allah ta'ala berfirman:

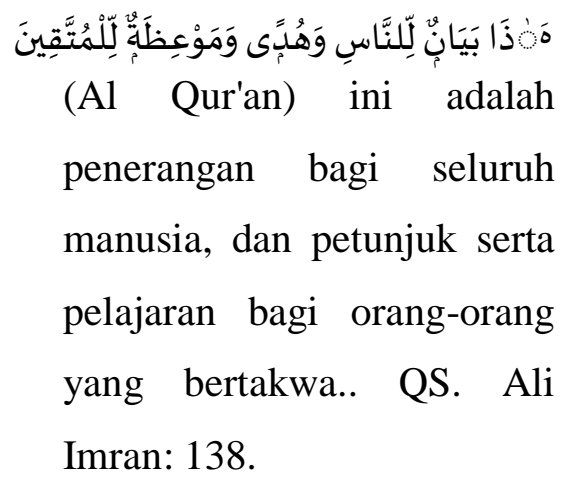

Sangat jelas sekali bahwa AlQur'an diturunkan sebagai penerang bagi seluruh umat manusia, bukan hanya masyarakat arab saja. Karena kebutuhan akan adanya petunjuk adalah kebutuhan seluruh umat manusia sehingga mereka juga berhak untuk mendapatkan petunjuk ke jalan yang benar tersebut.

Rasulullah sendiri walaupun berasal dari Arab namun bukanlah nabi yang diutus untuk orang arab saja, Allah ta'ala berfirman:

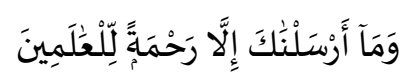

Dan tiadalah Kami mengutus kamu, melainkan untuk (menjadi) rahmat bagi semesta alam. (QS. AlAnbiya: 107)

Demikianlah keuniversalan syariah Islam, ia akan senantiasa sesuai untuk dilaksanakan kapan saja dan di mana saja. Hal ini disebabkan esensi dari syariahnya yang memiliki prinsipprinsip umum yang berkaitan dengan Tauhid, ibadah dan akhlak.

\section{Pilar Bangunan Islam}

\subsection{Tauhid}

Tauhid berasal dari bahasa Arab

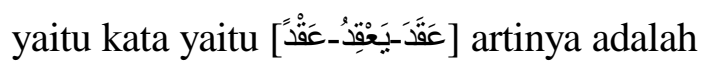
mengikat atau mengadakan perjanjian. Kata al-'aqdu (الْعَقُدُ) berarti ikatan, attautsiiqu (النََّّنْيُنْ) yang berarti kepercayaan atau keyakinan yang kuat, al-ihkaamu (الِْحْكَامُ) yang artinya mengokohkan (menetapkan), dan ar-rabthu biquw-wah (الرَّبْطُ بِقِقَةٍِ) yang berarti mengikat dengan 
kuat. Selain itu ia juga bermakna alIbraam (pengesahan), at-tamaasuk (pengokohan) dan al-itsbaatu (penetapan). Di antaranya juga mempunyai arti alyaqiin (keyakinan) dan al-jazmu (penetapan). "Al-'Aqdu" (ikatan) lawan kata dari al-hallu (penguraian, pelepasan). Kata ini diambil dari kata kerja: "'Aqadahu" "Ya'qiduhu" (mengikatnya), "Aqdan" (ikatan sumpah), dan "'Uqdatun Nikah" (ikatan menikah). Allah Ta'ala berfirman:

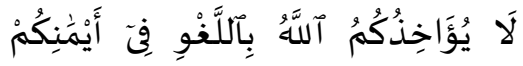

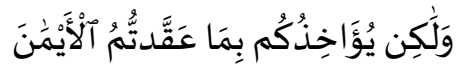

$$
\begin{aligned}
& \text { Allah tidak menghukum } \\
& \text { kamu disebabkan sumpah- } \\
& \text { sumpahmu yang tidak } \\
& \text { dimaksud (untuk bersumpah), } \\
& \text { tetapi Dia menghukum kamu } \\
& \text { disebabkan sumpah-sumpah } \\
& \text { yang kamu sengaja, maka } \\
& \text { kafarat (melanggar) sumpah } \\
& \text { itu. (QS. Al-Maidah: 89) }
\end{aligned}
$$

Sedangkan menurut istilah (terminologi): 'Tauhid adalah iman yang teguh dan pasti, yang tidak ada keraguan sedikit pun bagi orang yang meyakininya. Jadi, Akidah Islamiyyah adalah keimanan yang teguh dan bersifat pasti kepada Allah dengan segala pelaksanaan kewajiban, bertauhid dan taat kepada-Nya, beriman kepada Malaikat-malaikat-Nya, Rasul-rasulNya, Kitab-kitab-Nya, hari Akhir, takdir baik dan buruk dan mengimani seluruh apa-apa yang telah shahih tentang prinsip-prinsip Agama (Ushuluddin), perkara-perkara yang ghaib, beriman kepada apa yang menjadi ijma' (konsensus) dari Salafushalih, serta seluruh berita-berita qath'i (pasti), baik secara ilmiah maupun secara amaliyah yang telah ditetapkan menurut Al-Qur'an dan As-Sunnah yang shahih serta ijma' para shahabat Nabi.

\subsection{Akhlak}

Islam adalah agama yang sangat memperhatikan masalah etika atau akhlak, ia menjadi ciri bagi baiknya seseorang. Rasulullah Muhammad Shalallahu Alaihi Wasalam bersabda:

$$
\text { إِنَّمَا بُعِثْتُ لَأَتْمِمَ مَكَارِخَ الكَخْلاَقِ }
$$

Sesungguhnya aku diutus untuk menyempurnakan akhlak karimah. (HR. Malik)

Begitu pentingnya masalah akhlak dalam Islam sehingga hal-hal yang terkesan tidak bermanfaat-pun diatur oleh Islam, bahkan ia menjadi cirri bagi baiknya keislaman seseorang ketika 
mampu meninggalkannya. Hal ini bedasarkan sabda Rasulullah:

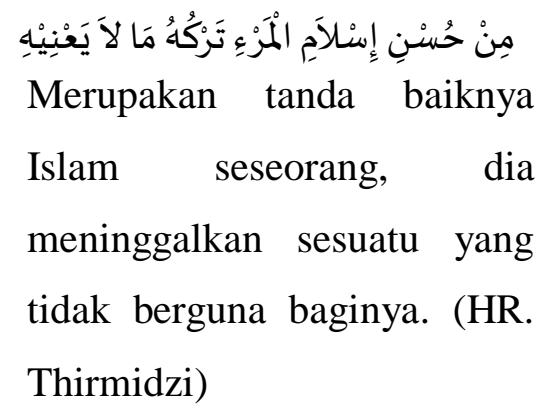

Secara umum dapat disebutkan bahwa syariah Islam adalah aturanaturan yang datang dari Allah ta'ala, ia berupa norma-norma yang ada di dalam Al-Qur'an dan As-Sunnah. Selain itu ia juga berupa hukum-hukum yang dihasilkan oleh para mujtahid yang disebut dengan fiqh Islam.

\subsection{Syariah}

Syari'ah adalah hukum-hukum yang mengatur hubungan manusia dengan Khaliq maupun dengan makhluk, di dalamnya terdiri dari dua unsur yakni Ibadah dan Muamalah. Dalam kontek yang lebih luas hukumhukum Syariah (ibadah dan muamalah) bertujuan mewujudkan dan melindungi 3 maslahat yaitu: maslahat utama (primer), maslahat penting (sekunder) dan maslahat penunjang (tertier). Maslahat utama ialah kebutuhan pokok hidup manusia yang meliputi agama, (dien), jiwa, harta, akal dan keturunan. Adapun maslahat penting ialah berbagai masalah yang dibutuhkan manusia agar hidup mereka dapat berjalan dengan mudah dan praktis, misalnya rukshoh, jual beli salam dalam muamalat, diaturnya hukum cerai, dan lain-lain. Sedangkan maslahat penunjang yaitu kebutuhan manusia akan berbagai hal, untuk menunjang kelangsungan hidup agar terasa indah dan nyaman, seperti disyariahkannya bersuci (thaharah).

Dalam ruang lingkup tujuan syariah para ulama merumuskan adanya lima tujuan diturunkannya syariah Islam ini yang dikenal dengan maqashid assyariah (maksud dan tujuan syariah), kelima maqashid tersebut adalah:

1. HifdzAd-Din

2. HifdzAn-Nafs

3. Hifdz Al-'Aql

4. Hifdz An-Nasab

5. Hifdz Al-Mal

Kelima tujuan dari syariah tersebut adalah ruh dari ajaran Islam, ia tidak bisa dipisahkan antara yang satu dengan yang lainnya. Berikut ini adalah penjelasannya: 
1. Hifdz Ad-Din (Menjaga Agama)

Sebagai bentuk penjagaan Islam terhadap agama (hifdz ad-din) maka Allah Ta'ala teah memerintahkan kepada hamba-hamba-Nya untuk melaksanakan ibadah. Di antara bentuk ibadah tersebut adalah shalat, zakat, puasa, haji, dzikir, do'a, dan lain-lain. Dengan menjalankan ibadah-ibadah tersebut maka akan tegaklah dien seseorang. Kemudian untuk menjaga keberadaan dien tersebut Allah ta'ala mensyariatkan jihad fi sabilillah, hal ini sebagaimana firman-Nya:

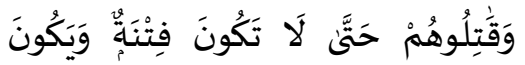

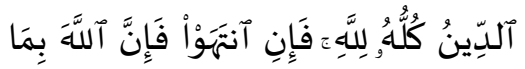

$$
\begin{aligned}
& \text { يَعْمَلُونَ بَصِيِِّ } \\
& \text { Dan perangilah mereka, } \\
& \text { supaya jangan ada fitnah dan } \\
& \text { supaya agama itu semata-mata } \\
& \text { untuk Allah. (QS. Al Anfal: }
\end{aligned}
$$

Kemudian untuk menjaga jangan sampai ada seorang muslim yang murtad setelah dia memeluk Islam, maka Allah mensyariatkan hukuman yang sangat keras bagi orang yang murtad, yaitu dihalalkan darahnya sebagaimana sabda Rasulullah:

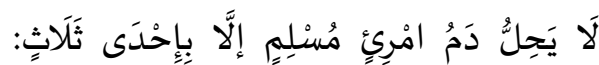

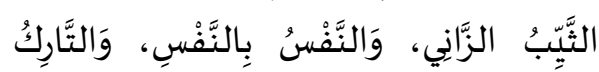

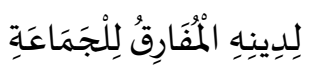

Tidaklah halal darah seorang muslim kecuali dengan tiga alasan: orang yang sudah menikah lalu berzina, jiwa dibalas dengan jiwa (hukum qishas) dan orang yang meninggalkan agamanya (murtad) yang berpisah dengan jama'ah. (HR. Bukhari dan Muslim)

Sebaliknya untuk meneguhkan hati orang yang baru memeluk Islam (muallaf) Allah syariatkan penyaluran zakat untuk mereka. Syariat Islam melarang adanya fitnah dalam dien. Fitnah di sini maksudnya semua upaya yang menghalangi manusia untuk menempuh jalan Allah yang lurus. Fitnah dalam hal ini jauh lebih besar bahayanya dari pembunuhan, sebagaimana firman Allah:

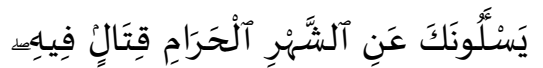

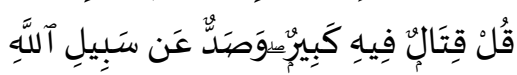

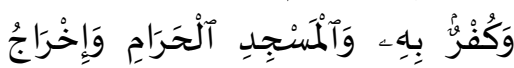

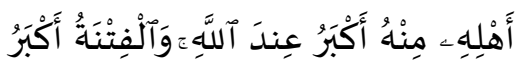

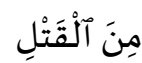

$$
\begin{aligned}
& \text { Mereka bertanya tentang } \\
& \text { berperang pada bulan Haram. } \\
& \text { Katakanlah:"Berperang dalam } \\
& \text { bulan itu adalah dosa besar; } \\
& \text { tetapi menghalangi (manusia) }
\end{aligned}
$$


dari jalan Allah, kafir kepada Allah, (menghalangi masuk) Masjidil Haram dan mengusir penduduknya dari sekitarnya, lebih besar (dosanya) di sisi Allah. Dan fitnah itu lebih besar (dosanya) dari pada membunuh. (QS. Al-Baqarah: 217)

Syariat Islam juga melarang keras siapa saja yang berusaha untuk merusak atau menyimpangkan Tauhid kaum muslimin atau menyebarluaskan pemahaman yang bid'ah (aliran sesat). Dalam rangka menjaga kebersihan dien seseorang, syariat Islam melarang tersebarnya apa saja yang berbau pornografi dan merusak akhlak.

2. Memelihara Jiwa (Hifdz AnNafs)

Islam melindungi seluruh umat manusia, maka dalam rangka menjaga keselamatan jiwa manusia dari pembunuhan tanpa alasan yang benar Allah ta'ala telah mengharamkan membunuh manusia tanpa alasan yang dibenarkan Islam. Jika terjadi sebuah pembunuhan maka wajib atasnya ditegakkan qishas:

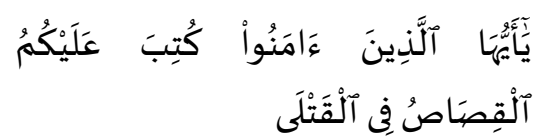

Hai orang-orang yang beriman, diwajibkan atas kamu qishaash berkenaan dengan orang-orang yang dibunuh. (QS. AlBaqarah: 178)

Selain larangan menghilangkan nyawa orang lain, Islam juga melarang seseorang untuk melakukan bunuh diri.

$$
\begin{aligned}
& \text { وَلَالَ تَقْتُلُوَا أَنْفَسَكُمْهَ إِنَّ آللَّهَ كَانَ بِكُمْ } \\
& \text { Dan janganlah kamu } \\
& \text { membunuh dirimu; } \\
& \text { sesungguhnya Allah adalah } \\
& \text { Maha Penyayang kepadamu. } \\
& \text { (QS. An-Nisaa: 29) }
\end{aligned}
$$

Syariat juga melarang seseorang menjatuhkan dirinya dalam kebinasaan:

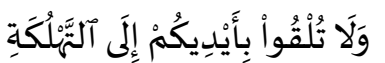

$$
\begin{aligned}
& \text { dan janganlah kamu }
\end{aligned}
$$

menjatuhkan dirimu sendiri ke dalam kebinasaan. (QS. AlBaqarah: 195)

Demikian juga semua perbuatan yang dapat membahayakan keselamatan jiwa atau merusak kesehatan fisik, seperti merokok, dan lain-lain. dilarang/diharamkan oleh syariat berdasarkan sabda Rasulullah: 


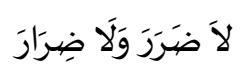

Tidak boleh ada sesuatu yang membahayakan diri sendiri dan tidak juga kepada orang lain. HR. Daruquthni, Ibnu majah dan Malik.

\section{Menjaga Akal (hifdz al-'aql)}

Syariat Islam melarang khamr (minuman keras), narkoba dan apa saja yang dapat merusak akal. Hal ini bertujuan untuk menjaga akal manusia dari apa saja yang dapat mengganggu fungsinya. Islam memandang bahwa akal manusia adalah anugrah dan nikmat Allah yang sangat besar. Dengan akal ini manusia menjadi lebih mulia dari pada makhluk-makhluk Allah yang lain. Maka termasuk dalam rangka mensyukuri ni'mat Allah tersebut syariat mewajibkan bagi seseorang untuk memelihara akalnya dari apa saja yang akan mengganggunya atau mengurangi fungsi kerjanya.

4. Menjaga Keturunan (hifdz annasb)

Untuk dapat menghasilkan keturunan syariat Islam menganjurkan umatnya untuk menikah. Dan untuk menjaga keturunan, syariat mengharamkan zina. Allah menyifati zina sebagai suatu kekejian dan jalan yang buruk, sebagaimana firman Allah:

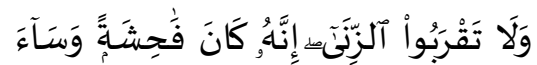

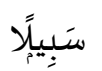

Dan janganlah kamu mendekati zina; sesungguhnya zina itu adalah suatu perbuatan yang keji. Dan suatu jalan yang buruk. (QS. Al-Isra: 32)

Syariat Islam memberikan hukuman yang keras bagi pelakunya baik perempuan ataupun laki-laki, sebagaimana firman Allah:

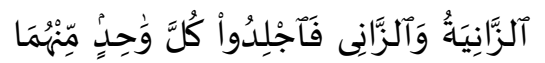

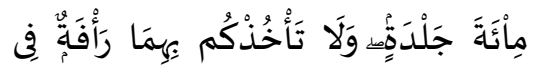

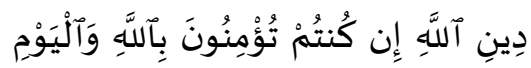

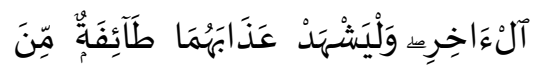
آلملْوَّمِنِينَ

Perempuan yang berzina dan laki-laki yang berzina, maka deralah tiap-tiap seorang dari keduanya seratus kali dera, dan janganlah belas kasihan kepada keduanya mencegah kamu untuk (menjalankan) agama Allah, jika kamu beriman kepada Allah, dan hari akherat, dan hendaklah (pelaksanaan) hukuman mereka disaksikan oleh sekumpulan dari orangorang yang beriman. (QS. AnNur: 2) 
Syariat Islam juga melarang seseorang membunuh anak-anaknya.

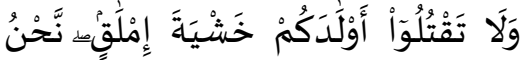

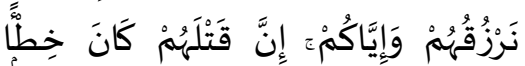

$$
\begin{aligned}
& \text { كَبيرًا }
\end{aligned}
$$

\section{Al-Isra: 31)}

Demikian juga perbuatan aborsi (menggugurkan kandungan) serta menelantarkan anak-anak dilarang dalam syariat.

\section{Menjaga Harta (hifdz al-maal)}

Untuk memperoleh harta yang halal, syariat Islam membolehkan berbagai macam bentuk muamalah, seperti jual beli, sewa-menyewa, gadai dan yang lainnya. Untuk menjaganya syariat Islam mengharamkan memakan harta manusia dengan jalan yang bathil, seperti; mencuri, riba, menipu, mengurangi timbangan, korupsi, dan lain-lain .

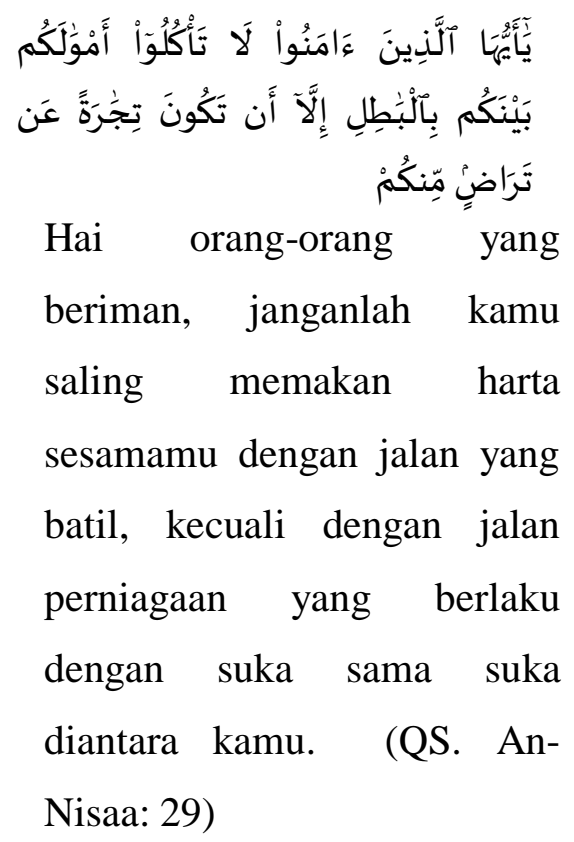

Syariat juga menetapkan hukuman yang keras bagi setiap pencuri.

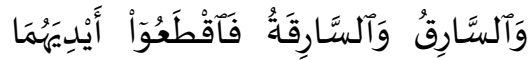

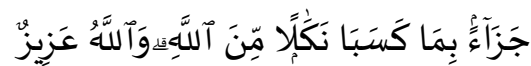

\section{حَكِيمِ}

Laki-laki yang mencuri dan perempuan yang mencuri potonglah tangan keduanya (sebagai) pembalasan dari apa yang mereka kerjakan dan sebagai siksaan dari Allah. Dan Allah Maha Perkasa lagi Maha Bijaksana. (QS. AlMaidah: 38)

Demikian juga syariat mengharamkan seseorang menghamburhamburkan hartanya untuk hal-hal yang tidak bermanfaat. 


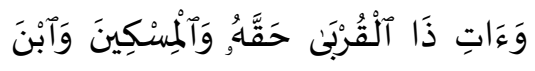

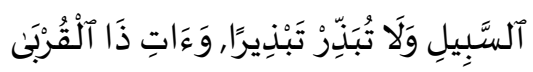

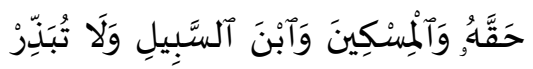

$$
\begin{aligned}
& \text { تَبَذِيرًا } \\
& \text { dan janganlah kamu } \\
& \text { menghambur-hamburkan } \\
& \text { (hartamu) secara boros. } \\
& \text { Sesungguhnya pemboros- } \\
& \text { pemboros itu adalah saudara- } \\
& \text { saudara syaitan dan syaitan itu } \\
& \text { adalah sangat ingkar kepada } \\
& \text { Rabbnya. (QS. Al-Isra: 26-27) }
\end{aligned}
$$

Dari maqashid syariah tersebut dapatlah kita pahami bahwa syariah Islam memberikan pedoman hidup bagi umat manusia, melindungi hak-hak mereka dan mengajak seluruh umat manusia untuk meraih kebahagiaan di dunia dan akhirat.

\subsubsection{Ruang Lingkup Syariah:} Ibadah dan Muamalah

Ibadah memiliki makna yang luas, ia mencakup segala sesuatu yang menjadi aktifitas manusia untuk menyembah kepada Allah ta'ala. Ibnu Taimiyah dalam kitab Al-Ubudiyyah mendefinisikan makna ibadah secara komprehensif:

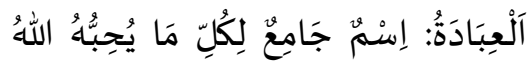

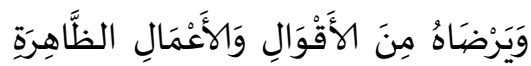

$$
\begin{aligned}
& \text { وَالْبَاطِنَة }
\end{aligned}
$$

Ibadah secara umum terbagi menjadi yaitu ibadah yang dhahir dan batin, ibadah yang dhahir adalah yang bisa disaksikan seperti shalat, membaca Al-Qur'an dan lain sebagaiinya. Sedangkan ibadah yang bathin adalah ibadah yang berkaitan dengan amalan hati seperti cinta kepada Allah, takut, berharap, tawakkal kepada-Nya dan lain-lain. Dengan definisi ini maka ibadah itu sangat luas tidak terbatas hanya shalat, zakat, puasa, haji dan lainnya akan tetapi semua ucapan dan perbuatan yang dicintai dan diridhai Allah maka itu adalah ibadah. Bagaimana untuk mengetahui bahwa suatu ucapan atau perbuatan itu dicintai dan diridhai Allah?

11 Ahmad Ibnu Taimiyyah. Majmuи'ul Fataawaa. Juz 10/149. 
Untuk mengetahui suatu ucapan atau perbuatan, apakah dicintai dan diridhai Allah atau tidak, maka harus merujuk kepada Al-Qur`an dan AsSunnah berdasarkan bimbingan ulama ahlus sunnah wal jama'ah, bukan berdasarkan pendapat atau kemauan sendiri. Dan juga harus diingat bahwa ucapan dan perbuatan tersebut dilakukan dengan ikhlash, hanya mengharap ridha Allah Ta'ala semata. Secara umum ibadah dibagi menjadi lima macam:

a) 'Ibaadah I'tiqaadiyyah: yaitu seorang muslim meyakini bahwasanya Allah 'Azza wa Jalla adalah Pencipta, Pemberi Rizki, yang Mematikan, Yang Menghidupkan, Yang Mengatur seluruh urusan hambahamba-Nya. Juga meyakini bahwasanya Dia adalah Dzat yang berhak diibadahi satu-satunya yang tidak ada sekutu bagi-Nya, dari do'a, menyembelih, nadzar dan yang lainnya, dan Dia adalah Dzat yang disifati dengan sifat-sifat kemuliaan, kesempurnaan, kesombongan, keagungan, dan yang lainnya dari macam-macam keyakinan tentang Allah, agama-Nya, malaikatmalaikat-Nya, kitab-kitab-Nya, rasul-
rasul-Nya, hari akhir dan taqdir yang baik maupun yang buruk.

b) 'Ibaadah Lafzhiyyah: yaitu ibadah yang berkaitan dengan ucapan lisan, seperti melafazhkan/mengucapkan dua kalimat syahadat, membaca AlQur`an, do'a, membaca dzikir-dzikir Nabawiyyah dan lain-lainnya dari jenis-jenis ibadah lafzhiyyah.

c) 'Ibaadah Badaniyyah: yaitu ibadah yang berkaitan dengan badan, seperti berdiri, ruku' dan sujud di dalam shalat, shaum, amalan-amalan haji, hijrah, jihad dan yang lainnya dari ibadah-ibadah badaniyyah.

d) 'Ibaadah Maaliyyah: yaitu ibadah yang berkaitan dengan harta, seperti zakat, shadaqah dan lainnya.

e) 'Ibaadah Tarkiyyah: yaitu seorang muslim meninggalkan seluruh hal-hal yang haram, kesyirikan dan bid'ah dalam rangka melaksanakan syari'at Allah, maka ini merupakan ibadah tarkiyyah darinya yang seorang muslim akan diberi pahala dari meninggalkan yang haram apabila meninggalkannya dalam rangka 
mengharap Wajah Allah. ${ }^{12}$ (AlQaulul Mufiid fii Adillatit Tauhid: 170-171).

\subsubsection{Muamalah:}

Secara bahasa kata muamalah adalah masdar dari kata 'amalayu'amili-mu'amalatan yang berarti saling bertindak, saling berbuat dan saling beramal. Fiqh muamalah memiliki dua macam pengertian, yaitu:

1. Pengertian fiqh muamalah dalam arti luas

2. Pengertian fiqh muamalah dalam arti sempit

Menurut Louis Ma'luf, pengertian muamalah adalah hukum-hukum syara yang berkaitan dengan urusan dunia, dan kehidupan manusia, seperti jual beli, perdagangan, dan lain sebagainya. Sedangkan menurut Ahmad Ibrahim Bek, menyatakan muamalah adalah peraturan-peraturan mengenai tiap yang berhubungan dengan urusan dunia, seperti perdagangan dan semua mengenai kebendaan, perkawinan, thalak, sanksi-sanksi, peradilan dan yang berhubungan dengan manajemen perkantoran, baik umum ataupun

${ }^{12}$ Al-Qaulul Mufiid fii Adillatit Tauhiid: hlm. 170-171. khusus, yang telah ditetapkan dasardasarnya secara umum atau global dan terperinci untuk dijadikan petunjuk bagi manusia dalam bertukar manfaat di antara mereka.

Pengertian fiqh muamalah yang dimaksud dalam buku ini adalah pengertian dalam arti sempit yaitu: "Muamalah adalah aturan Allah yang mengatur hubungan manusia dengan manusia dalam usahanya untuk mendapatkan alat-alat keperluan jasmaninya dengan cara yang paling baik" atau" Muamalah adalah tukar-menukar barang atu sesutu yang bermanfaat dengan cara-cara yang telah ditentukan"

Ruang lingkup yang dibahas dalam fiqh muamalah ini meliputi dua hal;

1. Muamalah adabiyah: yaitu ditinjau dari subjeknya atau pelakunya. Biasanya yang dibahas mengenai "harta" dan "ijab qobul"

2. Muamalah madiyah: ditinjau dari segi objeknya. Meliputi: al Ba'i (jual beli), Syirkah (perkongsian), al Mudharabah (Kerjasama), Rahn (gadai), kafalah dan dhaman (jaminan dan tanggungan), utang piutang, Sewa menyewa, hiwalah 
(pemindahan utang), sewa menyewa (ijarah), upah, syuf'ah (gugatan), Qiradh (memberi modal), Ji'alah (sayembara), Ariyah (pinjam meminjam), Wadi'ah (titipan), Musaraqah, Muzara'ah dan mukhabarah, Pinjam meminjam, Riba Dan beberapa permasalahan kontemporer (asuransi, bank dll), ihyaulmawat dan wakalah.

Muamalah dengan pengertian pergaulan hidup tempat setiap orang melakukan perbuatan dalam hubungan dengan orang lain yang menimbulkan hubungan hak dan kewajiban merupakan bagian terbesar dalam aspek kehidupan manusia. Oleh karenanya Islam menempatkan bidang muamalat sedemikian penting, hingga Rasulullah S.A.W. mengatakan, 'Agama adalah muamalah'. Berangkat dari hal itu semua, Islam bersikap lebih longgar dalam masalah hukum pada muamalah. Hukum Islam memberikan ketentuan bahwa pada dasarnya hukum dalam muamalah adalah mubah, hingga ada dalil atau nash yang mengharamkannya. Berbeda dengan ibadah yang hukum asalnya adalah haram, kecuali ada perintah atau tuntunan yang menganjurkan perbuatan ibadah tersebut.

4. Hasil dari Penerapan Syariah

4.1.Keadilan

Keadilan dipahami sebagai ketidakberpihakan kepada salah satu dari dua pihak, dalam makna yang khusus maka keadilan yang dimaksud adalah tidak terjadinya pertentangan antara seseorang dengan orang yang lainnya karena tidak ada satu orangpun yang terdzalimi.

Berlaku adil adalah salah satu prinsip Islam yang dijelaskan dalam berbagai nash ayat Al-Qur'an maupun hadits. Prinsip ini benar-benar merupakan akhlak mulia yang sangat ditekankan dalam syari'at Islam, sehingga wajar kalau tuntunan dan aturan agama semuanya dibangun di atas dasar keadilan dan seluruh lapisan manusia diperintah untuk berlaku adil.

Allah 'Azza wa Jalla berfirman,

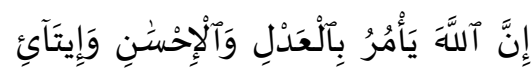

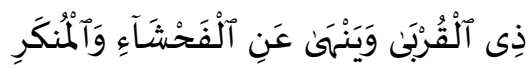

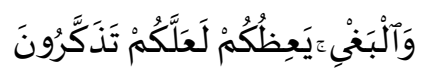
Sesungguhnya Allah menyuruh (kalian) berlaku adil, berbuat kebajikan dan 
memberi kepada kaum kerabat. Dan Allah melarang dari perbuatan keji, kemungkaran dan permusuhan. Dia memberi pengajaran kepada kalian agar kalian dapat mengambil pelajaran.” (QS. An-Nahl: 90)

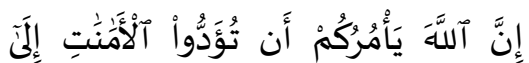

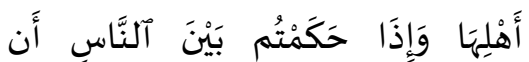

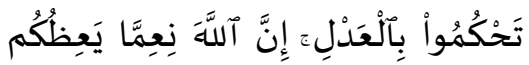

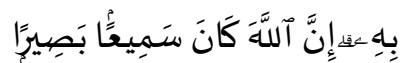

Sesungguhnya Allah menyuruh kalian menyampaikan amanat kepada yang berhak menerimanya, dan (menyuruh kalian) apabila menetapkan hukum di antara manusia supaya kamu menetapkan dengan adil. Sesungguhnya Allah memberi pengajaran yang sebaikbaiknya kepada kalian. Sesungguhnya Allah adalah Maha Mendengar lagi Maha Melihat.” (QS. An-Nisâ': 58)

Dan Al-Qur`an Al-Karîm adalah lambang keadilan,

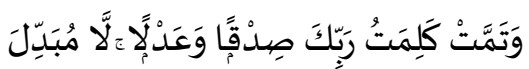

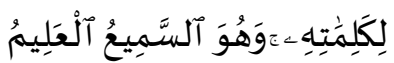

Telah sempurnalah kalimat Rabb-mu (Al-Qur`an), sebagai kalimat yang benar dan adil. Tidak ada yang dapat merobah-robah kalimatkalimat-Nya dan Dia-lah yang Maha Mendengar lagi Maha Mengetahui.” (QS. Al-An'âm: 115)

Dan Allah Ahkamul Hâkimîn memerintah untuk berlaku adil secara mutlak:

$$
\text { وَإِذَا قُلْتُمْ فَاعْعِدِلُواُ وَلَوٌْ كَانَ ذَا قُرْبَى }
$$

Dan apabila kamu berkata, maka hendaklah kamu berlaku adil kendatipun dia adalah kerabat(mu)." (QS. Al-An'âm: 152)

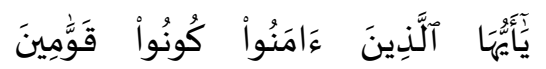

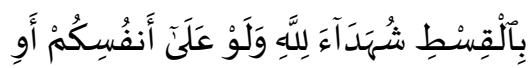

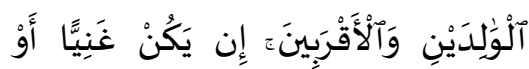

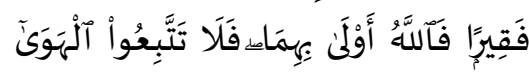

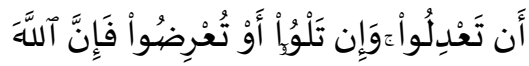

$$
\text { كَانَ بِمَا تَعْمَلَوُونَ خَبِيًِا }
$$

Wahai orang-orang yang beriman, jadilah kalian orang yang benar-benar penegak keadilan, menjadi saksi karena Allah, biarpun terhadap diri kalian sendiri atau ibu bapak dan kaum kerabat kalian. Jika 
ia kaya ataupun miskin, maka Allah lebih tahu kemaslahatannya. Maka janganlah kalian mengikuti hawa nafsu karena ingin menyimpang dari kebenaran. Dan jika kalian memutar balikkan (kata-kata) atau enggan menjadi saksi, maka sesungguhnya Allah adalah Maha Mengetahui segala apa yang kamu kerjaan.” (QS. AnNisầ: 135)

\section{Rabbul 'Izzah tetap} memerintahkan untuk berlaku adil walaupun terhadap musuh sendiri,

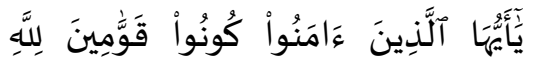

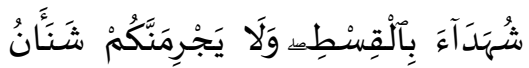

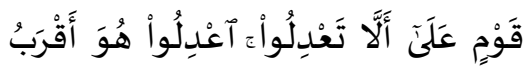

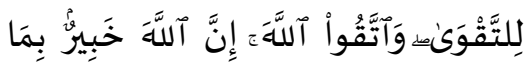
تَعْمَلُونَ لَتَِْ

Hai orang-orang yang beriman, hendaklah kamu jadi orang-orang yang selalu menegakkan (kebenaran) karena Allah, menjadi saksi dengan adil. Dan janganlah sekali-kali kebencianmu terhadap sesuatu kaum, mendorong kamu untuk berlaku tidak adil. Berlaku adillah, karena adil itu lebih dekat kepada takwa. Dan bertakwalah kepada Allah, sesungguhnya Allah Maha Mengetahui apa yang kamu kerjakan.” (QS. Al-Mầidah: 8)

Dan Allah memuji orang-orang yang berlaku adil,

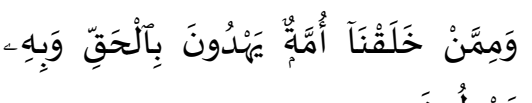
يَحْدِلْونَ

"Dan di antara orang-orang yang Kami ciptakan ada umat yang memberi petunjuk dengan hak, dan dengan yang hak itu (pula) mereka menjalankan keadilan.” (QS.

Al-A'râf: 181)

Dan Nabi-Nya telah diperintah untuk menyatakan,

$$
\begin{aligned}
& \text { وَأُمِرْتُ لِأَعْدِدلَ بَيْنَكُمُ } \\
& \text { "Dan aku diperintahkan } \\
& \text { supaya berlaku adil di antara } \\
& \text { kalian.” (QS. Asy-Syûrô: 15) }
\end{aligned}
$$

Allah Ta'ala dalam ayat-ayat tersebut memerintahkan bagi seluruh umat Islam untuk senantiasa berbuat adil. Keadilan dalam makna luas yaitu menempatkan sesuatu pada tempatnya dan tidak berat sebelah. Lebih tegas lagi 
keadilan adalah segala sesuatu yang disandarkan kepada perintah Allah dan Rasul-Nya. Itulah keadilan yang sebenarnya walaupun menurut manusia tampak tidak adil.

Keadilan dalam hak berarti memberikan hak bagi masing-masing pemiliknya sebagaimana ditetapkan dalam syariah Islam. Sebagai contoh hak bagi anak laki-laki dalam masalah waris adalah dua kali anak perempuan, sementara perempuan mendapatkan satu bagian dari laki-laki. Ini adalah sebuah keadilan yang telah diatur oleh Allah ta'ala dalam syariah-Nya. Selain itu keadilan dalam hak berarti keadilan yang telah ditetapkan Allah ta'ala di dalam Al-Qur'an dan As-Sunnah yang shahih.

Keadilan dalam bidang sosial ekonomi adalah keadilan yang memberikan strata kehidupan manusia sama dalam pandangan Islam. Tidak ada keistimewaan antara satu orang dengan orang lainnya. Apalgi jika hanya dilihat dari keturunan (nasab) harta, kedudukan atau karena pangkat dan jabatan. Islam memandang bahwa seluruh manusia memiliki derajat yang sama, yang membedakan hanyalah ketakwaan seseorang. Sehingga keadilan dalam Islam di bidang sosial adalah bahwa setiap manusia memiliki derajat yang sama sebagai makhluk Allah yang harus diperlakukan sebagaimana hamba Allah lainnya.

Keadilan sosial di bidang ekonomi berarti setiap manusia memiliki akses yang sama untuk bekerja, mendapatkan penghasilan dan memperoleh hasil dari usahanya. Tidak boleh adanya monopoli dan kepemilikan yang sifatnya menjadikan kemudharatan bagi orang lain dan masyarakat pada umumnya. Keadilan ekonomi juga berarti bahwa masyarakat yang tidak memiliki kemampuan untuk bekerja menjadi tangguungan negara untuk memenuhi kebutuhan hidupnya. Negara bertanggungjawab terhadap kehidupan anak-anak yatim, fakir miskin, orangorang jompo dan mereka yang membutuhkan bantuan di bidang ekonomi. Secara umum negara bertanggungjawab terhadap warga negaranya sebagai bentuk keadilan ekonomi.

Keadilan di bidang hukum berarti setiap manusia memiliki kedudukan yang sama di mata hukum. Tidak ada 
perbedaan seorang raja, presiden atau pejabat dengan masyarakat biasa. Ketika ia bersalah maka harus dihukum. Inilah yang telah dicontohkan oleh Nabi Muhamma S.A.W., beliau bersabda:

$$
\text { لقطع الله: لو أن فاطمة بنت محمد سرقت }
$$

Demi Dzat yang Muhammad berada dalam genggamanNya. Kalau seandainya Fatimah binti Muhammad mencuri. Niscaya aku akan memotong tangannya.

Demikianlah ketegasan Nabi yang mulia, beliau akan menegakan keadilan walaupun berupa hukuman terhadap putrinya sendiri. Islam tidak pernah membeda-bedakan derajat seseorang di depan hukum, siapa yang bersalah maka harus dihukum. Kesalahan hukum di zaman kita ini adalah bahwa hukum itu bisa dibeli sehingga seseorang yang bersalah akan bisa lepas dari hukuman kalau dia berasal dari kalangan pejabat atau orang-orang yang memiliki kekuasaan dan punya uang, mereka membeli hukum dengan menyuap para hakim agar mereka terbebas dari hukuman.

\subsection{Keamanan}

Keamanan adalah suatu hal yang dituntut dalam kehidupan, dimana seluruh makhluk sangat membutuhkannya dalam memenuhi halhal yang berkaitan dengan mashlahat kepentingan mereka, baik yang sifatnya keduniaan maupun keagamaan. Dan tiadalah seorang insan yang hidup di muka bumi ini kecuali ia pasti mencari sebab-sebab keamanan untuk dirinya dan mencurahkan segenap kemampuannya guna menjauhi sebabsebab ketakutan yang boleh jadi akan mendatangkan ancaman bahaya dalam perjalanan hidupnya. Bagaimanapun seorang manusia meraih keselamatan badan dan keluasan rizki, maka hal tersebut tidaklah bernilai dan tiada terasa manfaatnya kecuali dengan keamanan dan ketentraman.

Betapapun manusia diberikan sebab-sebab kemajuan dan segala unsur keberhasilan, maka ia tidak akan mencapai kebahagiaannya dan tidak pula dapat menuai kehidupan yang indah kecuali dengan tuntunan dan syari'at yang Allah 'Azza wa Jalla, Sang Pencipta manusia ridhoi untuk mereka.

Kita bersyukur dan memuji Allah Jalla Jalâluhu yang telah menerangkan 
segala sebab keamanan dalam agama kita. Dan kita senantiasa menyanjungNya atas segala kemurahan yang diantaranya adalah dijadikannya syari'at Islam ini sebagai syari'at yang bertujuan menegakkan keamanan di tengah manusia. Nabi 'Ibrâhim 'alaihissâlam pada awal mula beliau menginjakkan kakinya di kota Makkah, beliau berdoa kepada Rabb-Nya:

$$
\begin{aligned}
& \text { وَإِذْ قَالَ إِبْرَهِهمُ رَبِّ آَجْعَلْ هُذَا بَلَلًَا }
\end{aligned}
$$

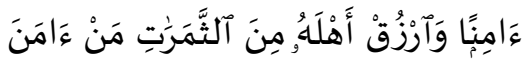

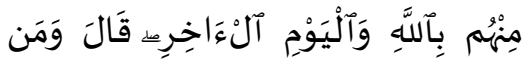

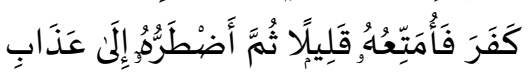

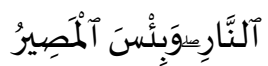

Setelah beliau merintis kota Makkah, maka beliau dengan perintah Allah meninggalkan keluarganya di negeri baru tersebut untuk sementara waktu. Kemudian beliau kembali lagi ke negeri tersebut dan beliau berdoa kepada-Nya,

$$
\begin{aligned}
& \text { وَإِذْ قَالَ إِبْرَهِيمُ رَبِّ آجْعَلْ هُذَا أْلْبَلَدَ }
\end{aligned}
$$

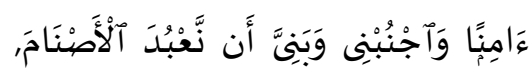

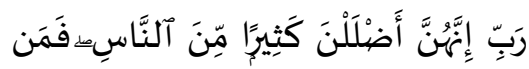

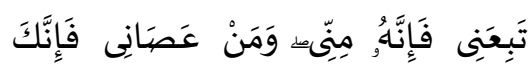

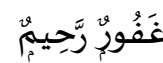

Ya Rabb-ku, jadikanlah negeri ini (Mekah), negeri yang aman, dan jauhkanlah aku beserta anak cucuku daripada menyembah berhala-berhala. Ya Rabb-ku, sesungguhnya berhala-berhala itu telah menyesatkan kebanyakan daripada manusia, maka barangsiapa yang mengikutiku, maka sesungguhnya orang itu termasuk golonganku, dan barangsiapa yang mendurhakai aku, maka sesungguhnya Engkau, Maha Pengampun lagi Maha Penyayang.” (QS. Ibrâhim: 35-36)

Dalam dua teks ayat di atas, Nabi Ibrâhîm 'alaihissalam memulai doanya dengan memohon keamanan untuk kota Makkah. Hal tersebut karena Nabi Ibrahim 'alaihissalam sangat mengetahui bahwa keamanan adalah lambang kebahagiaan masyarakat, 
bangsa dan negara, dan dengan keamanan akan tercapai segala kemashlahatan dan kebaikan yang dibutuhkan oleh manusia.

Allah Ta'ala mengingatkan nikmat keamanan kepada penduduk tanah haram dan kepada seluruh makhluk agar mereka senantiasa mengingat nikmat tersebut dan bersyukur kepada Allah karenanya dan beribadah kepada-Nya di bawah naungaNya:

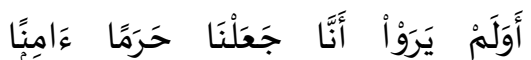

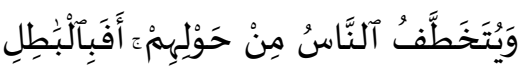

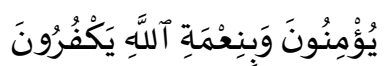

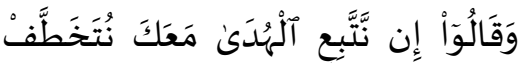

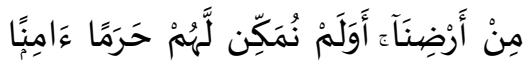

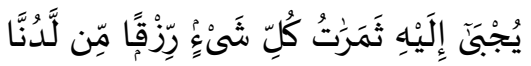

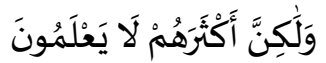

$$
\begin{aligned}
& \text { Dan apakah Kami tidak } \\
& \text { meneguhkan kedudukan } \\
& \text { mereka dalam daerah haram }
\end{aligned}
$$

(tanah suci) yang aman, yang didatangkan ke tempat itu buah-buahan dari segala macam (tumbuh-tumbuhan) untuk menjadi rezki (bagimu) dari sisi Kami?. Tetapi kebanyakan mereka tidak mengetahui." (QS. AlQashash: 57)

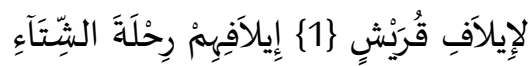

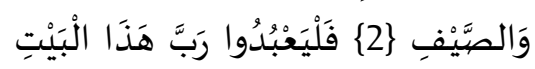

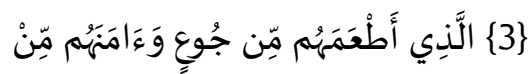

$$
\begin{aligned}
& \text { خَوْفِ }
\end{aligned}
$$

Allah 'Azza Dzikruhu telah memberikan nikmat keamanan kepada Tsamud, kaumnya Nabi Shôleh 'alahissalâm dengan kemampuan mereka memahat gunung sebagai rumah-rumah mereka tanpa ada ketakutan dan kecemasan, dan Allah Ta'âlâ melimpahkan kepada mereka nikmat yang sangat banyak yang datang 
silih berganti dan memberikan mereka tempat tinggal yang aman, dimana Allah 'Azza wa Jalla berfirman:

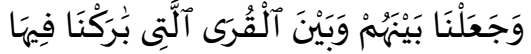

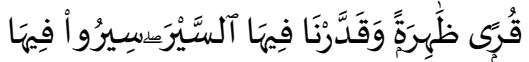

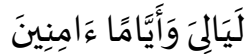

$$
\begin{aligned}
& \text { Dan Kami jadikan antara } \\
& \text { mereka dengan negeri-negeri } \\
& \text { yang Kami limpahkan berkat } \\
& \text { kepadanya, beberapa negeri } \\
& \text { yang berdekatan dan Kami } \\
& \text { tetapkan antara negeri-negeri } \\
& \text { itu (jarak-jarak) perjalanan. } \\
& \text { Berjalanlah kalian di kota-kota } \\
& \text { itu pada malam dan siang hari } \\
& \text { dengan aman." (QS. Saba`: }
\end{aligned}
$$

Yusuf 'alaihissalâm ketika menyambut kedua orang tua dan keluarganya, beliau mengingatkan nikmat keamanan yang dilimpahkan terhadap mereka dengan masuknya mereka ke negeri yang aman dan tentram dengan penuh kesejukan jiwa,

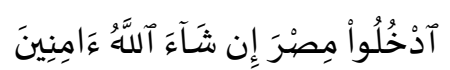

Masuklah kalian ke negeri Mesir, insya Allah dalam keadaan aman.” (QS. Yûsuf: 99)
Bahkan di antara kenikmatan penduduk sorga di dalam sorga adalah tempat yang aman tanpa ada rasa takut sedikit pun dan tanpa kecemasan,

$$
\text { آَدْخُلُوهَا بِسَلَعِ عَامِينِينَ }
$$

(Dikatakan kepada penduduk sorga): "Masuklah ke dalamnya dengan sejahtera lagi aman"." (QS. Al-Hijr: 46)

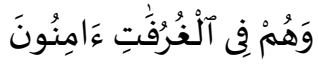

Dan mereka aman sentosa di tempat-tempat yang tinggi (dalam surga)." (QS. Saba': 37)

$$
\begin{aligned}
& \text { إِنَّ الْمتَّقَِينَ فِي مَقَامِ أَمِينٍ } 151\} \text { فِيَ جَنَّاتٍ } \\
& \text { وَعُيُونٍ } \\
& \text { وَإِسنَتَبْرَقٍِ }
\end{aligned}
$$

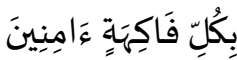

Sesungguhnya orang-orang yang bertakwa berada dalam tempat yang aman, (yaitu) di dalam taman-taman dan berbagai mata air; mereka memakai sutera yang halus dan sutera yang tebal, (duduk) berhadap-hadapan,

demikianlah. Dan Kami berikan kepada mereka bidadari. Di dalamnya mereka 
meminta segala macam buahbuahan dengan aman (dari segala kekhawatiran)." (QS. Ad-Dukhân: 51-55)

Sungguh syari'at Islam telah mengumpulkan seluruh jenis kebaikan; Islam menjaga syari'at dan tuntunan, melindungi dan memelihara akal-akal manusia, mensucikan harta benda, memberi keamanan kepada jiwa-jiwa manusia, dan menebarkan segala bentuk keselamatan, ketenangan, rahmat dan kesejahteraan. Rasulullâh shollallahu 'alaihi wa 'ala alihi wa sallam bersabda,

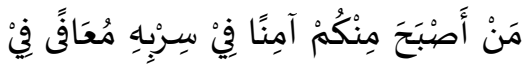

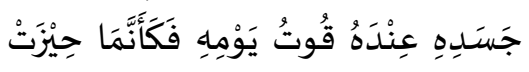

$$
\begin{aligned}
& \text { لََهُ الدُّنْيَا }
\end{aligned}
$$

Islam menjaga keamanan jiwa manusia hingga pada tempat yang paling aman sekalipun, seperti masjid-masjid. Rasulullâh shollallahu 'alaihi wa 'ala alihi wa sallam bersabda,

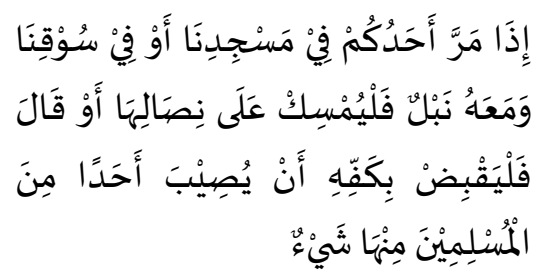

Apabila salah seorang dari kalian berlalu di mesjid kami atau di pasar kami dangan membawa tombak, maka hendaknya ia memegang ujungnya, atau beliau berkatahendaknya ia menggenggam dengan tangannya, agar tidak ada sesuatupun dari senjatasenjata tersebut yang menimpa salah seorang dari kaum muslimin."

Sekadar memunculkan sebabsebab ketakutan di tengah kaum muslimin adalah hal yang terlarang dalam syari'at Islam. Rasulullâh shollallâhu 'alaihi wa 'ala alihi wa sallam bersabda,

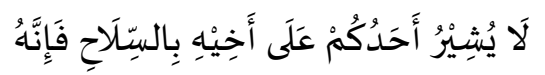

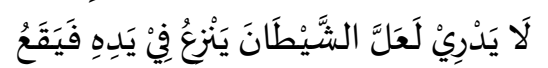

$$
\begin{aligned}
& \text { فِيْ حُفْرَةٍ مِنَ النَّارِ لَّرِ }
\end{aligned}
$$


sebab tangannya sehingga ia terjerumus ke dalam jurang neraka."

Dan syari'at ini telah mengharamkan atas setiap muslim untuk berisyarat dengan suatu jenis senjata kepada saudaranya seislam, walaupun hanya bercanda. Rasulullâh shollallâhu 'alaihi wa 'ala alihi wa sallam bersabda,

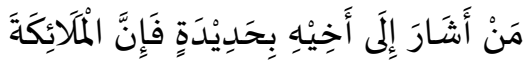

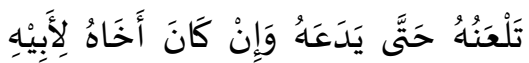

$$
\begin{aligned}
& \text { وَأُمِِّـ }
\end{aligned}
$$

Barang siapa yang berisyarat kepada saudaranya dengan sebuah besi, maka sesungguhnya Malaikat melaknatnya hingga ia meninggalkannya, walaupun ia adalah saudaranya sebapak dan seibu.

Membuat takut seorang muslim adalah perkara yang diharamkan dengan segala bentuknya. Nabi shollallâhu 'alaihi wa 'ala alihi wa sallam bersabda,

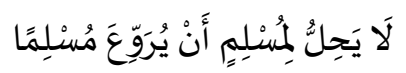

Tidak halal bagi seorang muslim membuat takut muslim yang lain.

Nabi shollallâhu 'alaihi wa 'ala alihi wa sallam bersabda,

$$
\text { مَنْ حَمَلَ عَلَينَا السِّنَاْحَ فَلَيْنَنَ مِنَّا }
$$

\begin{abstract}
Barang siapa yang mengangkat senjata terhadap kami, maka ia bukan dari golongan kami."
\end{abstract}

Beliau juga menegaskan,

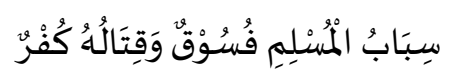
Mencela seorang muslim adalah kefasikan dan membunuhnya adalah kekufuran."

Nabi shollallâhu 'alaihi wa 'ala alihi wa sallam bersabda,

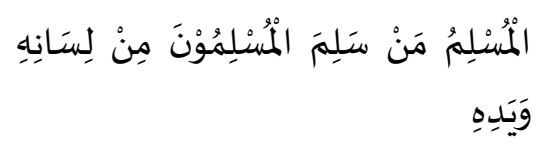

Seorang muslim adalah orang yang kaum muslimin (lainnya) selamat dari gangguan lisan dan tangannya.

Sebagai penjagaan terhadap keamanan dan ketentraman, Nabi shollallâhu 'alaihi wa 'ala alihi wa sallam marah kepada siapa saja yang memberikan syafa'at dalam pelaksanaan had (hukuman) dari had-had Allah 'Azza wa Jalla setelah perkara itu sampai kepada penguasa, dimana beliau shollallahu 'alaihi wa 'ala alihi wa sallam menegaskan hal tersebut dalam sabdanya, 


$$
\begin{aligned}
& \text { لَوْ أَنَّ فَاطِمَاََ بَنْتَ مُحَمَمَّدٍ سَرَقَتْ } \\
& \text { لَقَطَعْتُ يَدَهَا } \\
& \text { Andaikata Fathimah }
\end{aligned}
$$

\subsection{Kemakmuran}

Kemakmuran adalah kondisi di mana masyarakat dapat merasakan kehidupan yang tercukupi kebutuhannya baik secara moril maupun materiil. Menurut Ibnu Taimiyah, kemakmuran dalam persepsi Islam bertujuan untuk mencapai moral kehidupan yang baik. Beliau juga menambahkan bahwa akan banyak sekali kewajiban agama yang tidak dapat dijalankan jika kemakmuran belum dicapai. Dan masyarakat yang tidak mencapai kemakmuran secara otomatis sulit menjalankan agamanya secara kaffaah (totalitas) termasuk dalam hal ibadahnya kepada Allah Subhanahu wa Ta'ala. Sehingga oleh sebab itulah Islam sangat menganjurkan agar umat manusia mau mencapai kehidupan dunia yang lebih baik (hasanat fid duniya) karena hal itu berkorelasi dengan upaya mencapai hasanat fil akhirat.
Ibnu Taimiyah sangat menolak sikap hidup yang menjauhi keduniaan sebagaimana dianuti oleh kalangan sufi ortodok. Bahkan beliau berpendapat bahwa keduniaan harus diraih oleh umat Islam sebagai sarana untuk mencapai kemampuan dalam memenuhi kewajiban dan menjauhi hal-hal yang dilarang. Oleh sebab itu pula Ibnu Taimiyah berkesimpulan bahwa syarat mutlak untuk mewujudkan masyarakat Islam yang sebenar-benarnya ialah harus dicapai lebih dulu kemakmuran umat. Kemiskinan justru akan menghambat umat Islam untuk menjadi kaaffah. Dan kemiskinan merupakan penghalang utama bagi mewujudkan masyarakat Islam yang utama dan yang sebenarbenarnya.

Dalam pandangan Ibnu Taimiyah, kemakmuran jauh berbeda dengan kekayaan semata. Kemakmuran lebih tinggi kedudukannya daripada kekayaan, keduanya (antara kemakmuran dan kekayaan) saling berinteraksi dan membutuhkan. Kekayaan akan meningkatkan hak, sementara kemakmuran mengarahkan kepada upaya pencapaian kewajiban. Dan oleh sebab itulah Islam 
berpandangan bahwa orang kaya adalah mitra potensial bagi orang miskin, orang miskin sangat diperlukan oleh orang kaya.

Henri Laoust menyatakan kekagumannya terhadap pemikiran Ibnu Taimiyah tentang kemakmuran diatas, beliau menyatakan: "doktrin Ibnu Taimiyah sangat mendorong pengorganisasian secara aktif didalam penerapan ekonomi masyarakat dengan alasan bahwa dengan ketiadaan organisasi semacam itu, kemakmuran akan mandeg dan kemudian akan cenderung menyusut dan akhirnya menghilang semuanya. Dalam sejumlah hal, Ibnu Taimiyah telah melampaui pemikiran ilmuwan lainnya terutama dalam kajian kemakmuran ini yang sangat mengagumkan untuk sebuah tesis pemikiran di penghujung abad ke 7 Hijriyah masa itu.

\subsection{Persaudaraan}

Setiap muslim adalah bersaudara, demikianlah yang tercantum di dalam Al-Qur'an:

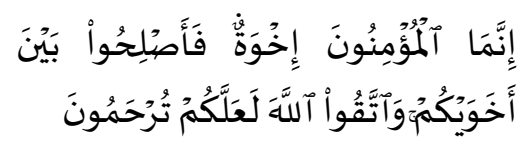

Sesungguhnya orang-orang mu'min itu bersaudara kerena itu damaikanlah antara kedua saudaramu dan bertakwalah kepada Allah Subhanahu wa Ta'ala supaya kamu mendapat rahmat. (QS. AlHujuraat: 10)

Semua muslim adalah bersaudara. Karena itu jika bertengkar mereka harus bersatu kembali dan bersaudara seperti biasanya. Hal ini diperkuat oleh larangan Rasulullah S.A.W. terhadap permusuhan antar muslim. Abu Ayyub Al-Anshary meriwayatkan bahwa Rasulullah S.A.W. bersabda "Tidak seorang muslim memutuskan silaturrahmi dengan saudara muslimnya lebih dari tiga malam yang masingmasingnya saling membuang muka bila berjumpa. Yang terbaik di antara mereka adalah yang memulai mengucapkan salam kepada yang lain.”

Persaudaraan yang dimaksudkan adalah bukan menurut ikatan geneologi tapi menurut ikatan iman dan agama. Hal tersebut diisyarakat dalam larangan Allah Subhanahu wa Ta'ala mendoakan orang yg bukan Islam setelah kematian mereka. Firman Allah Subhanahu wa Ta'ala "Tiadalah sepatutnya bagi nabi dan orang-orang yang beriman meminta 
ampun bagi orang-orang musyrik walaupun orang-orang musyrik itu adalah kerabatnya."

Ini sama sekali tidak berarti bahwa seorang muslim diijikankan mengabaikan ikatan keluarganya walaupun dangann kerabat non muslim. Dasar kebajikan kepada orang tua dan keluarga dapat ditemukan dalam AlQur'an sendiri. Firman Allah Subhanahu wa Ta'ala "Dan kami wajibkan manusia kebaikan kepada kedua ibu bapaknya."

\section{Mengutamakan persaudaraan} Islam lebih dari yang lain sama sekali tidak mempengaruhi ikatan darah biarpun dangan kerabat non-Muslim. Nabi S.A.W. menekankan pentingnya membangun persaudaraan Islam dalam batasan-batasan praktis dalam bentuk saling peduli dan tolong menolong. Sebagai contoh Beliau bersabda "Allah Subhanahu wa Ta'ala menolong hambaNya selama hamba itu menolong saudaranya". Bodoh sekali seorang muslim yang mengharapkan belas kasih khusus dari Allah Subhanahu wa Ta'ala jika ia tidak memiliki kepedulian terhadap kesejahteraan muslim lainnya.
Sebagai akibatnya persaudaraan kaum muslim tidak saja merupakan aspek teoritis ideologi Islam tapi telah terbukti dalam praktek aktual pada kaum muslim terdahulu ketika mereka menyebarkan Islam ke penjuru dunia. Kemanapun orang-orang Arab muslim pergi apakah itu ke Afrika India atau daerah-daerah terpencil Asia mereka akan disambut hangat oleh orang-orang yang telah memeluk Islam tanpa melihat warna kulit ras atau agama lamanya. Tidak ada tempat dalam Islam bagi pemisahan kelas maupun kasta. Tata cara melaksanakan shalat tidak ada tempat istimewa dan semua harus berdiri bahu membahu dalam baris-baris lurus. Demikian pula dalam pemilihan imam tidak didasarkan status sosialnya dalam masyarakat namun atas kemampuannya dalam menghafal al-Qur'an.

Itulah mengapa seorang imam dapat ditunjuk dari anak yg berusia enam tahun sebagaimana kejadian pada seorang shahabat muda Salamah. Nabi S.A.W. mengatakan pada kabilahnya "Jika waktu shalat tiba slah seorang dari kalian harus mengumandangkan adzan". Ketika mereka mencari di antara mereka sendiri mereka tidak menemukan orang 
yang tahu tentang Al-Qur'an lebih dari Salamah sehingga mereka menunjuknya sebagai imam walaupun ia baru berusia enam atau tujuh tahun pada saat itu.

Pilar ketiga dalam Islam zakat berupa kewajiban atas orang-orang kaya atau relatif kaya untuk menyerahkan sebagian dari simpanan tahunan mereka kepada orang-orang miskin merupakan perwujudan tanggung jawab sosial ekonomi dari persaudaraan itu. Sebab walaupun kedermawanan amat dianjurkan oleh Islam sebagaimana oleh agama lain tanggung jawab ini dalam Islam dilembagakan dan dipungut oleh negara untuk menjamin kelangsungan hidup ekonomi orang-orang miskin.

Sebenarnya semua hukum-hukum ekonomi dalam Islam selalu menekankan perlindungan atas hak-hak persaudaraan. Praktek-praktek ekonomi yang dengan suatu cara menarik keuntungan atau merugikan anggotaangota masyarakat adalah terlarang keras. Makanya pinjaman yang diaku dalam Islam adalah pinjaman tanpa bunga sebab pinjaman dengan bunga pada umumnya mengambil keuntungan yang tidak adil dari orang lain ketika mereka dalam posisi yang secara ekonomis lemah.

Demikian pula pilar terbesar Islam haji yang mengandung esensi pilar-pilar lainnya menekankan persaudaraan orang-orang beriman dalam semua ritusritusnya. Pakaian bagi orang-orang lakilaki yang sedang haji dikenal dengan Ihram terdiri dari dua lembar kain selembar dipakai seputar pinggang selembar yang lain diselempangkan di atas bahu. Kesederhanaan pakaian ini dikenakan oleh jutaan jamaah haji dari berbagai penjuru dunia menunjukan hakekat persatuan dan persamaan dalam persaudaraan Islam.

Keaslian prinsip persaudaraan yang meliputi segala upacara keagamaan dan hukum-hukum dalam Islam telah dan terus menjadi faktor kunci dalam menarik manusia di seluruh dunia untuk masuk Islam. Namun patut dicatat bahwa prinsip persaudaraan ini telah ditantang dalam prakteknya oleh munculnya nasionalisme di antara kaum muslimin. Walaupun Allah Subhanahu wa Ta'ala dan Rasul-Nya dengan tegas menentang segala bentuk tribalisme nasionalisme dan rasisme. Nasionalisme telah ditimbul di kalangan kaum muslim 
setelah tumbangnya generasi awal Berabad-abad setelah wafatnya Nabi S.A.W. nasionalisme arab Persia dan Turki meruntuhkan umat muslim ketika kepemmpinan terus berpindah tangan di antara mereka selama masa-masa itu.

Bentuk awal nasionalisme ini kemudian diperberat oleh kolonialisme Eropa yg meninggalkan umat Islam terpecah belah ke dalam seribu satu kesatuaan-kesatuan nasional yang berskala kecil dan dangkal. Walaupun ikatan umum Islam tetap berlanjut menyatukan umat dalam persaudaraan pemerintah mereka masing-masing mengeksploitasi segala kesempatan yang dapat membangkitkan perasaanperasaan nasionalisme agar massa muslim tetap terpecah-pecah sehingga pemerintahan mereka yang pada sebagian besar kasus anti Islam dapat terus terpelihara.

Kelemahan yang menghantam kehidupan umat Islam sekarang ini mulai dari runtuhnya khilafah Islamiyah sampai terpuruknya negeri-negeri Islam sehingga harus menjadi bagian dunia ketiga merupakan satu indikasi yang paling jelas menurunnya rasa persaudaraan di kalangan umat Islam itu sendiri. Perpecahan di kalangan umat yang mempunyai kepentingankepentingan golongan ikut meluluh lantahkan pilar-pilar persaudaraan itu. Maka kata kunci utk mampu menegakan Islam di seantero jagad ini adalah dengan pererat persaudaraan di antara sesama umat Islam dan menyingkirkan jauh-jauh rasa ta'asubiyah dan keyakinan penuh bahwa nasionalisme bukan dari bagian kita sedikitpun.

\section{PENUTUP}

Islam adalah way of life, peraturan yang bersifat integral yang mengatur hidup dan kehidupan ummat manusia dan menjadi dasar akhlak yang mulia yang dibawa oleh Nabi Muhammad S.A.W. untuk disampaikan kepada ummat manusia. Islam memiliki seperangkat peraturan yang lengkap sehingga menjadikannya memiliki sifat komprehensif dan universal. Komperhensifitas Islam terbukti dari peraturan yang lengkap yang membahas seluruh sendi kehidupan manusia. Universalisme Islam terbukti dari pelaksanaannya yang bisa dilakukan oleh siapa saja, kapan saja, di mana saja dan dalam keadaan bagaimanapun juga. 
Maksud dan tujuan diturunkannya syariah Islam ini dikenal dengan maqashid as-syariah (maksud dan tujuan syariah) mempunyai 5 (lima) tujuan, kelima maqashid (tujuan) tersebut adalah: Hifdz Ad-Din (menjaga agama), Hifdz An-Nafs (menjaga jiwa), Hifdz Al-'Aql (menjaga akal), Hifdz AnNasab (menjaga keturunan) dan Hifdz Al-Mal (menjaga harta).

Bangunan Islam terdiri dari Tauhid (aqidah), Syariah dan moral. Ketiganya menjadi pilar dalam pengembangan Islam sebagai agama yang komprehensif dan universal.

Syariat Islam bersifat qath'i karena bersumber dari Allah dan RasulNya yang ada dalam Al-Qur'an dan As-Sunnah. Sedangkan Fiqh adalah pemahaman seorang mujtahid terhadap nash (teks) Al-Qur'an dan Al-Hadits.

Hasil dari revitalisasi penerapan syariah Islam adalah keadilan, keamanan, kemakmuran dan persaudaraan bagi ummat manusia.

\section{DAFTAR PUSTAKA}

Al Quran Al Karim

Abdalati, H. (1407/1986). Islam Suatu Kepastian. Jakarta: I.I.F.S.O.

Maududi A. A. (1407 H/ 1986). PrinsipPrinsip Islam. Jakarta: International Islamic Federation of Student Organizations.

\section{Al-Qaulul Mufiid fii Adillatit Tauhiid}

At-Tamimi, S. M. Tiga Landasan Utama, Islamic Propagation Office in Rabwah, Riyadh, tanpa tahun.

Bahreisy, S., Bahreisy, H. S. Terjemah Singkat Tafsir Ibnu Katsir, Jilid I, CV Diponegoro, Bandung.

Bahreisy, S., Bahreisy, H. S. Terjemah Singkat Tafsir Ibnu Katsir.

Mandzur, Ibnu, Lisan Al- 'Arab Juz VI.

Shihab, M. Quraish "Wawasan Al Quran “, Jakarta: Penerbit Mizan, 1499 H/ 1999.

Taimiyyah, A. I. Majmuи'ul Fataawaa, Juz 10/149.

Zaidan, A. K. (1979). Dasar-dasar Ilmu Dakwah (1). Jakarta: Media Dakwah. 